\title{
Hubungan Katian-Anion dalam Pergerakan dan Pencucian Hara pada Tanah Typic Hapludult di Taman Nasional Bukit Duabelas
}

\section{Cation-Anion Relationship on Movement and Leaching of Nutrients on The Typic Hapludult Soil at Bukit Duabelas National Park}

\author{
Gilang Sukma Putra ${ }^{\mathrm{a}}$, Arief Hartono ${ }^{\mathrm{b}}$, Syaiful Anwar ${ }^{\mathrm{b}}$, Kukuh Murtilaksono ${ }^{\mathrm{b}}$ \\ a Program Studi Ilmu Tanah, Sekolah Pascasarjana, Institut Pertanian Bogor, Kampus IPB Dramaga, Bogor, 16680 [+6282213540587] \\ ${ }^{\mathrm{b}}$ Departemen Ilmu Tanah dan Sumberdaya Lahan, Fakultas Pertanian, Institut Pertanian Bogor, Kampus IPB Dramaga, Bogor, \\ $16680[+622528629360]$
}

\section{Article Info:}

Received: 21 - 08 - 2018

Accepted: 02 - $07-2019$

Keywords:

Cation-anion correlation, nutrient movement, leaching, typic hapludult, Bukit Duabelas National Park.

Corresponding Author:

Arief Hartono

Departemen Ilmu Tanah dan

Sumberdaya Lahan, Fakultas

Pertanian, Institut Pertanian

Bogor;

Tel. +62-251-8629360, +62812-

1108-782

Email: hartono@apps.ipb.ac.id

\begin{abstract}
Soil nutrient content is dependent on the amount and movement of cation-anion in the soil solution. This research was conducted to determine the amount of dissolved cations-anions in soil solutions and to evaluate their relationship in the tropical rainforest soil of Bukit Duabelas National Park (TNBD). Lisymeters are installed on each soil horizon of the Typic Hapludult soil to hold percolated water. The accumulated water sample was extracted and each cation $\left(\mathrm{NH}_{4}^{+}, \mathrm{Ca}^{2+}, \mathrm{Mg}^{2+}, \mathrm{K}^{+}\right)$and anions concentration $\left(\mathrm{PO}_{4}{ }^{3-}, \mathrm{Cl}^{-}\right.$ , $\left.\mathrm{SO}_{4}^{2-}, \mathrm{NO}^{3-}\right)$ were measured. Data were analyzed using Spearman correlation and stepwise linear regression modeling. The results show that the total cations and anions are significantly higher in the AO horizon than the $A B$ and $B$ horizons. The cation has a strong correlation to each anion (correlation value $>0.80$ ). The regression model shows that $\mathrm{NH}_{4}^{+}$has the strongest relationship to $\mathrm{NO}_{3}{ }^{-}, \mathrm{PO}_{4}{ }^{3-}$, and $\mathrm{Cl}^{-}$with $\mathrm{R}^{2}$ adj. $=0.75, \mathrm{Ca}^{2+}$ to $\mathrm{NO}_{3}{ }^{-}$ , $\mathrm{PO}_{4}{ }^{3-}$, and $\mathrm{SO}_{4}{ }^{2-}\left(\mathrm{R}^{2}\right.$ adj. $\left.=0.856\right), \mathrm{Mg}^{2+}$ to $\mathrm{NO}_{3}{ }^{-}$and $\mathrm{PO}_{4}{ }^{3-}\left(\mathrm{R}^{2}\right.$ adj. $\left.=0.815\right)$, and $\mathrm{K}^{+}$to $\mathrm{PO}_{4}^{3-}$ and $\mathrm{Cl}^{-}\left(\mathrm{R}^{2}\right.$ adj. $\left.=0.845\right)$. It can be concluded that $\mathrm{NO}_{3}{ }^{-}, \mathrm{Cl}^{-}$, $\mathrm{SO}_{4}{ }^{2-}$, and $\mathrm{PO}_{4}{ }^{3-}$ are directly involved as agents of co-pairing cations in soil nutrient movements and leaching processes.
\end{abstract}

How to cite (CSE Style $8^{\text {th }}$ Edition):

Putra GS, Hartono A, Syaiful A, Murtilaksono K. 2019. Hubungan kation-anion dalam pergerakan dan pencucian hara pada tanah. JPSL 9(4): 960-969. http://dx.doi.org/10.29244/jps1.9.4. 960-969.

\section{PENDAHULUAN}

Neraca hara merupakan alat diagnostik yang penting untuk menentukan keberlanjutan kesuburan tanah. Perubahan total jumlah hara tanah dihitung sebagai keseimbangan massa masukan (input) dan keluaran (output) hara (van der Heijden et al. 2012). Dalam suatu ekosistem, masukan hara dapat berupa deposisi atmosfer dan dekomposisi bahan organik dan mineral, sedangkan keluaran hara dapat terjadi melalui mekanisme pencucian hara (leaching). Tingginya curah hujan di daerah tropis dapat meningkatkan mobilitas ion-ion terlarut dalam tanah (Clare dan Mack 2011). Anion dalam larutan tanah lebih mudah bergerak dan tercuci oleh aliran massa air karena interaksi yang lemah dengan muatan dominan negatif pada permukaan jerapan tanah. Sebagai konsekuensinya, pergerakan kation yang terbawa oleh anion akan menjadi lebih besar.

Penelitian terdahulu menemukan bahwa terdapat hubungan kation-anion dalam proses mobilisasi di dalam tanah. Chicota et al. (2014) menemukan bahwa sulfat bersama-sama dengan kalsium membentuk suatu paired adsorption complex dalam larutan tanah. Sedangkan pergerakan nitrat dalam larutan tanah berasosiasi dengan ion kalsium dan magnesium. Kation-kation basa dan beberapa anion merupakan unsur-unsur hara 
esensial bagi tanaman. Ketersediannya dalam tanah sangat dibutuhkan. Namun ketika sebagian besar hara tidak dijerap tanah dan diserap tanaman, maka jumlahnya dalam ekosistem tanah akan berkurang dan berpotensi tercuci. Pencucian sejumlah hara akan menimbulkan berbagai masalah lingkungan seperti eutrofikasi (Thorburn et al. 2013), pencucian $\mathrm{SO}_{4}{ }^{2-}$ (sulfat) yang dapat meningkatkan ketersedian ion asam $\mathrm{H}^{+}$ dan $\mathrm{Al}^{3+}$ dalam larutan tanah (Garg et al. 2015), juga kehilangan kalsium dan magnesium dari ekosistem tanah yang dapat menurunkan kesuburan tanah (Hartemink 2008).

Mobilitas unsur-unsur hara beragam dari tanah satu ke tanah lainnya, tergantung pada jenis vegetasi dan bahan induk serta karakteristik pencucian unsur-unsur hara yang khas menurut lokasinya. Penelitian tentang pergerakan unsur-unsur hara pada daerah tropis masih terbatas. Informasi mengenai besaran jumlah massa ionion hara dalam tanah sangat diperlukan. Oleh karena itu, kajian dasar mengenai jumlah kation dan anion dalam larutan tanah perlu dilakukan untuk menduga status kesuburan tanah dan ketersediannya terhadap tanaman. Lebih lanjut, perlu dilakukan evaluasi terhadap hubungan kation dan anion pada ekosistem tanah. Penelitian ini bertujuan untuk memberikan informasi besaran jumlah kation-anion dalam larutan tanah dan mengevaluasi hubungan pergerakan kation-anion dalam larutan tanah.

\section{METODE}

\section{Lokasi dan Waktu Penelitian}

Penelitian ini dilakukan di hutan hujan tropis Taman Nasional Bukit Duabelas, Kabupaten Sarolangun, Provinsi Jambi dengan koordinat lokasi $02^{\circ} 00^{\prime} 13.9^{\prime \prime}$ LS dan $102^{\circ} 45^{\prime} 13.2^{\prime \prime}$ BT. Pengambilan sampel dilakukan pada tanah typic hapludut, yang termasuk ordo Ultisol, dan merupakan tanah yang memiliki keterbatasan sifat fisik dan kimia yang dapat menjadi masalah dalam membangun suatu tegakan. Penelitian dilakukan mulai dari bulan April hingga September 2015. Ekstraksi sampel air dilakukan di Laboraturium Kimia dan Kesuburan Tanah, Departemen Ilmu Tanah dan Sumberdaya Lahan, Fakultas Pertanian, Institut Pertanian Bogor. Sedangkan pengukuran kation dan anion terlarut $\left(\mathrm{NH}_{4}^{+}, \mathrm{Ca}^{2+}, \mathrm{Mg}^{2+}, \mathrm{K}^{+}, \mathrm{NO}_{3}{ }^{-}, \mathrm{PO}_{4}{ }^{3-}, \mathrm{Cl}^{-}\right.$, $\mathrm{SO}_{4}{ }^{2-}$ ) dilakukan di Laboraturium Terpadu, Badan Penelitian Tanah.

\section{Metode Pengumpulan Data}

\section{Rancangan Percobaan Lapang}

Enam profil tanah dibuat pada transek lereng dari lembah hingga puncak. Ditentukan tiga titik transek lereng dengan ulangan dua profil pada setiap titik sehingga terdapat 6 buah profil tanah. Setiap profil tanah dilakukan pemasangan lisimeter, lisimeter yang digunakan adalah jenis free-draining lysimeter, merupakan jenis lisimeter dengan bagian atas terbuka dan dapat menampung air berdasarkan aliran gravitasi. Mengacu pada metode pengambilan sampel bahan terlarut yang dilakukan Arifin (2016), setiap lisimeter dipasang secara horizontal dengan memasukkan lembaran tampungan $\left(200 \mathrm{~cm}^{2}\right)$ pada masing-masing horizon $\mathrm{AO}, \mathrm{AB}$, dan $\mathrm{B}$ yang dihubungkan dengan selang dan botol tampungan air cucian di bagian bawah profil. Pada setiap botol kolektor diberikan larutan $\mathrm{CuBr}_{2} 0.1 \mathrm{M}$ untuk menghentikan aktivitas organisme agar kandungan solut dalam botol penampung tidak terkontaminasi (Fujii et al. 2011).

\section{Pengambilan sampel}

Pengambilan sampel dilakukan sebanyak 4 kali setiap 45-60 hari dan merupakan sampel air hasil perkolasi pada lisimeter yang dialirkan ke botol kolektor pada setiap lapisan horizon profil tanah. Volume air tampungan diukur langsung pada saat pengamatan lapang, kemudian sekitar $600 \mathrm{ml}$ air dibawa untuk dilakukan analisa laboraturium dengan menggunakan botol kolektor lain. Sampel ditaruh di dalam cooler box untuk menjaga sampel agar tetap aman dan tidak rusak selama perjalanan. 


\section{Perlakuan sampel air pra analisis}

Mengacu pada metode ekstraksi yang dilakukan Fujii et al. (2008), sebelum dilakukan pengukuran sampel air diekstrak terlebih dahulu dengan filter cellulose acetate membrane $0.45 \mu \mathrm{m}$ menggunakan vacump pump dengan tujuan untuk memisahkan partikulat tanah dan bahan organik solid dalam air sehingga dapat dipastikan hanya bahan terlarut saja yang tersisa. Sampel air diekstrak sebanyak $100 \mathrm{~mL}$, kemudian filtrat air disimpan pada ruangan dingin dan terhindar dari cahaya matahari langsung untuk menjaga kemurnian sampel.

\section{Pengukuran konsentrasi kation dan anion terlarut}

\section{a. Ion Amonium $\left(\mathrm{NH}_{4}^{+}\right)$}

Amonium dalam filtrat air diukur langsung secara kolorimetri menggunakan spektrofotometer dengan metode Biru Indofenol (Sudjadi dan Widjik, 1972; Menon, 1973dalam Eviati dan sulaeman, 2009). Deret standar $\mathrm{N}(0.0 ; 0.25 ; 0.5 ; 1.0 ; 1.5 ; 2.0 ; 2.5 \mathrm{ppm})$ dibuat dengan mengencerkan larutan standar $\mathrm{N}_{-} \mathrm{NH}_{4}{ }^{+} 1000$ ppm secara bertahap. Kemudian dilakukan pengukuran dengan spektrofotometer pada panjang gelombang 636 $\mathrm{nm}$. Setiap deret standar amonium diukur besaran nilai absorbansinya, kemudian dibuat kurva standar dengan persamaan regresi linier dimana konsentrasi amonium sebagai variabel Y (terikat) dan absorbansi sebagai variabel X (bebas). Konsentrasi amonium pada sampel dapat dihitung dengan memasukan nilai absorbansi yang tercatat pada spektrofotometer dengan persamaan regresi linier pada deret standar amonium.

\section{b. Ion Kalsium $\left(\mathrm{Ca}^{2+}\right)$, Magnesium $\left(\mathrm{Mg}^{2+}\right)$, dan Kalium $\left(\mathrm{K}^{+}\right)$}

Kalsium dan magnesium dalam filtrat air diukur dengan metode Spektrofotometer Serapan Atom (SSA), sedangkan kalium diukur dengan metode emisi (Menon 1973; Rayment dan Higginson 1992 dalam Eviati dan Sulaeman 2009). Pembuatan deret standar masing-masing kation dilakukan dengan mengencerkan larutan standar Ca, Mg, dan K 1000 ppm secara bertahap. dengan deret standar seperti pada Tabel 1.

Tabel 1 Deret standar ion kalsium, magnesium, dan kalium.

\begin{tabular}{cccccccc}
\hline Deret standar & $\mathrm{S} 0$ & $\mathrm{~S} 1$ & $\mathrm{~S} 2$ & $\mathrm{~S} 3$ & $\mathrm{~S} 4$ & $\mathrm{~S} 5$ & $\mathrm{~S} 6$ \\
\cline { 2 - 8 } Kation & & & \multicolumn{7}{c}{$\mathrm{ppm}$} & & \\
\hline $\mathrm{Ca}^{2+}$ & 0.0 & 2.5 & 5.0 & 10.0 & 15.0 & 20.0 & 25.0 \\
$\mathrm{Mg}^{2+}$ & 0.0 & 0.1 & 0.2 & 0.4 & 0.6 & 0.8 & 1.0 \\
$\mathrm{~K}^{+}$ & 0.0 & 0.5 & 1.0 & 2.0 & 3.0 & 4.0 & 5.0 \\
\hline
\end{tabular}

Pengukuran $\mathrm{Ca}$, dan $\mathrm{Mg}$ dilakukan dengan alat ukur Atomic absorbance spectrophotometer (AAS), dan pengukuran K dengan Flamephotometer. Setiap deret standar diukur besaran nilai absorbansi/emisinya, kemudian dibuat kurva standar dengan persamaan regresi linier dimana konsentrasi kation sebagai variabel Y dan absorbansi/emisi sebagai variabel X. Konsentrasi kation pada sampel dihitung dengan memasukan nilai absorbansi/emisi yang tercatat pada spektrofotometer dan flamefotometer masing-masing pada persamaan regresi linier deret standar.

c. Ion Nitrat $\left(\mathrm{NO}_{3}^{-}\right)$

Nitrat dalam filtrat air diukur langsung dengan metode spektrofotometri pada nilai absorban $210 \mathrm{~nm}$ dan $275 \mathrm{~nm}$ (APHA,1998 dalam Eviati dan Sulaeman, 2009). Pembuatan deret standar nitrat (0.0; 0.5; 1.0; 2.0;

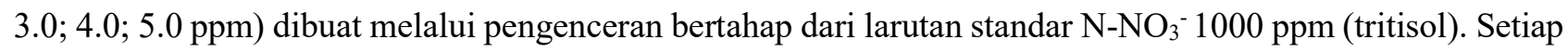
sampel dan deret standar dipipet sebanyak $5 \mathrm{~mL}$ ke dalam tabung reaksi, kemudian diukur dengan menggunakan spektrofotometer UV masing-masing pada panjang gelombang $210 \mathrm{~nm}$ dan $275 \mathrm{~nm}$. Pengenceran dilakukan jika nilai absorban sampel lebih tinggi dibandingkan absorban standar yang paling tinggi. Karena bahan organik terlarut memiliki kemungkinan mengabsorb UV sedangkan nitrat tidak mengabsorb UV pada panjang gelombang $275 \mathrm{~nm}$, maka pengukuran pada panjang gelombang $275 \mathrm{nmperlu}$ 
dilakukan. Nilai absorban pada $210 \mathrm{~nm}$ dikurangi 2.5 kali absorban dari pembacaan pada 275 nmuntuk mendapatkan pembacaan absorban oleh nitrat. Setiap deret standar nitrat diukur besaran nilai absorbansinya, kemudian dibuat kurva standar dengan persamaan regresi linier dengan konsentrasi nitrat sebagai variabel Y dan absorbansi sebagai variabel X. Konsentrasi nitrat pada sampel dapat dihitung dengan memasukan nilai absorbansi yang tercatat pada spektrofotometer pada persamaan regresi linier deret standar nitrat.

\section{d. Ion Fosfat $\left(\mathrm{PO}_{4}{ }^{3-}\right)$}

Fosfat dalam filtrat air diukur langsung secara kolorimetri menggunakan spektrofotometer dengan metode biru molibdat(Sudjadi dan Widjik, 1972; Menon, 1973dalam Eviati dan Sulaeman, 2009). Deret standar fosfat $(0.0 ; 0.25 ; 0.50 ; 1.00 ; 1.50 ; 2.00 ;$ dan $2.50 \mathrm{ppm})$ dibuat dengan pengenceran bertahap dari larutan standar fosfat $1000 \mathrm{ppm}$. Pengukuran fosfat dilakukan dengan spektrofotometer padapanjang gelombang $889 \mathrm{~nm}$. Setiap deret standar diukur besaran nilai absorbansinya, kemudian dibuat kurva standar dengan persamaan regresi linier dimana konsentrasi fosfat sebagai variabel Y dan absorbansi sebagai variabel X. Konsentrasi fosfat pada sampel dapat dihitung dengan memasukan nilai absorbansi yang tercatat pada spektrofotometer pada persamaan regresi linier deret standar fosfat.

e. Ion Klorida $\left(\mathrm{Cl}^{-}\right)$

Klorida dalam filtrat air diukur langsung dengan metode argentometri (Sudjadi dan Widjik, 1972dalam Eviati dan Sulaeman, 2009). Setiap sampel dipipet sebanyak $10 \mathrm{~mL}$ dan ditambahkan larutan penunjuk kalium kromat 5\% sebanyak 4 tetes, kemudian dititrasi dengan $\mathrm{AgNO}_{3} 0.01 \mathrm{~N}$ sampai warna larutan berubah merah. Volume $(\mathrm{mL})$ larutan penitar yang diperlukan dicatat, kemudian blanko dibuat dengan memipet 10 mLakuades lalu dititrasi kembali. Konsentrasi klorida dapat dihitung dengan rumus;

$$
\left[\mathrm{Cl}^{-}\right] \mathrm{meL}^{-1}=(\mathrm{mL} \text { sampel }-\mathrm{mL} \text { blangko }) \times \mathrm{N} \times(1000 \mathrm{~mL} / \mathrm{mL} \text { sampel })
$$

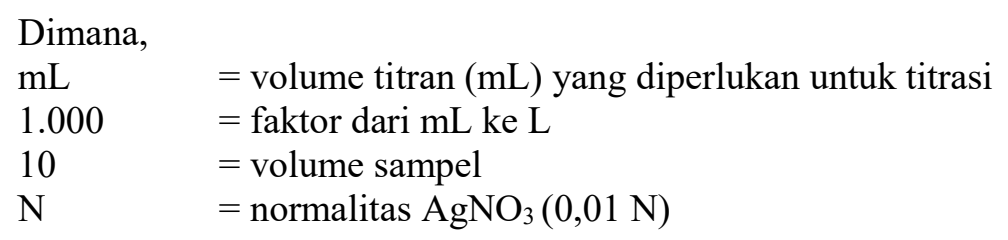

\section{f. Ion Sulfat $\left(\mathrm{SO}_{4}{ }^{2-}\right)$}

Ion sulfat dalam filtrat air diukur langsung secara turbidimetri (Sudjadi dan Widjik, 1972dalam Eviati dan Sulaeman, 2009). Sampel dan deret standar $(0.0 ; 0.5 ; 1.0 ; 2.0 ; 3.0 ; 4.0 ; 5.0 \mathrm{ppm})$ dipipet sebanyak $5.0 \mathrm{~mL}$ ke dalam tabung reaksi. kemudian ditambahkan $1 \mathrm{~mL}$ pereaksi asam campur dan dikocok. Lalu ditambahkan 1 $\mathrm{mL}$ larutan $\mathrm{BaCl}_{2}$-Tween, dikocok dan dibiarkan 15 menit. Sampel diukur dengan spektrofotometer pada panjang gelombang $494 \mathrm{~nm}$ menggunakan deret standar sebagai pembanding. Setiap deret standar diukur besaran nilai absorbansinya, kemudian dibuat kurva standar dengan persamaan regresi linier dimana konsentrasi sulfat sebagai variabel $\mathrm{Y}$ dan absorbansi sebagai variabel $\mathrm{X}$. Konsentrasi sulfat pada sampel dapat dihitung dengan memasukan nilai absorbansi yang tercatat pada spektrofotometer dengan persamaan regresi linier pada deret standar sulfat.

\section{Metode Analisis Data}

\section{Pergerakan dan pencucian kation-anion}

Air di dalam tanah bergerak bersama-sama dengan bahan terlarut (kation dan anion), maka massa ion terlarut dapat diduga dengan pendekatan perhitungan massa air (Van der Heijden et al.,2012). Besarnya massa ion terlarut dihitung dengan mengkalikan konsentrasi ion terlarut(solute) dengan volume air drainase (Arifin, 2016). 
Putra GS, Hartono A, Syaiful A, Murtilaksono K

$$
\sum \text { ion }=\mathbf{C}_{\text {solute }} \cdot \mathbf{V}_{\text {drinagewater }}
$$

Dimana:

Sion $\quad=$ Massa ion terlarut $(\mathrm{mg})$

$\mathbf{C}_{\text {solute }} \quad=$ Konsentrasi ion terlarut $\left(\mathrm{mg} \mathrm{L}^{-1}\right)$

$\mathbf{V}_{\text {drinagewater }}=$ Volume air $(\mathrm{L})$

\section{Analisis hubungan pergerakan kation-anion}

Analisis uji beda rata - rata independen $t$-student digunakan untuk mengevaluasi perbedaan massa pencucian kation dan anion terlarut pada setiap horizon tanah. Analisis korelasi Spearman dilakukan untuk mengetahui hubungan pergerakan kation-anion.

\section{Analisis hubungan kation-anion dalam pergerakan dan pencucian hara}

sedangkan analisis regresi liniear berganda dilakukan untuk mengidentifikasi anion-anion yang paling erat hubungannya dengan kation dalam proses pergerakan dan pencucian hara dalam larutan tanah, serta mencari pola hubungan matematik antara peubah kation tersebut dengan peubah beberapa anion. Dilakukan analisis regresi stepwise untuk menghindari terjadinya multikolinearitas dalam regresi (Erizilina 2018). Prosedur stepwise merupakan metode pemilihan model di mana algoritma komputer menentukan model mana yang lebih disukai. Prosedur ini menggunakan urutanparsial $\mathrm{F}$ atau uji $\mathrm{t}$ untuk mengevaluasi signifikansivariabel (Rahman et al. 2014). Setiap tahap model dievaluasi agar tidak terjadiredundansi. Analisis data seluruhnya dilakukan dengan menggunakan software SPSS 25 dan Microsoft Excell 2013.

\section{HASIL DAN PEMBAHASAN}

\section{Pergerakan dan pencucian kation-anion}

Total besaran massa kation memiliki nilai yang berbeda antara satu kation dengan kation lainnya. Berdasarkan data pada Tabel 2 diketahui bahwa semua kation (amonium, kalsium, magnesium, dan kalium) memiliki total jumlah paling tinggi pada horizon $\mathrm{AO}$, diikuti horizon $\mathrm{AB}$, dan yang terendah pada horizon $\mathrm{B}$. Selama selang waktu 138 hari pengamatan, total pencucian amonium pada horizon AO sebesar $15.75 \mathrm{~kg} / \mathrm{ha}$ lebih tinggi dibanding horizon $\mathrm{AB}(1.09 \mathrm{~kg} / \mathrm{ha})$ dan $\mathrm{B}(1.01 \mathrm{~kg} / \mathrm{ha})$. Kalsium mengalami pencucian tertinggi pada horizon $\mathrm{AO}(6.6 \mathrm{~kg} / \mathrm{ha})$, diikuti oleh horizon $\mathrm{AB}(1.19 \mathrm{~kg} / \mathrm{ha})$ dan $\mathrm{B}(0.46 \mathrm{~kg} / \mathrm{ha})$. Magnesium mengalami pencucian tertinggi pada horizon $\mathrm{AO}(4.48 \mathrm{~kg} / \mathrm{ha})$ yang diikuti oleh horizon $\mathrm{AB}(0.47 \mathrm{~kg} / \mathrm{ha})$ dan yang terendah pada horizon B $(0.08 \mathrm{~kg} / \mathrm{ha})$. Kalium mengalami pencucian tertinggi pada horizon AO $(28.18 \mathrm{~kg} / \mathrm{ha})$ diikuti oleh horizon $\mathrm{AB}(3.26 \mathrm{~kg} / \mathrm{ha})$ dan terendah pada horizon B $(0.44 \mathrm{~kg} / \mathrm{ha})$.

Tabel 2 Total massa kation-anion terlarut pada setiap horizon/

\begin{tabular}{|c|c|c|c|}
\hline \multirow{3}{*}{ Kation/anion } & \multicolumn{3}{|c|}{ Horizon } \\
\hline & $\mathrm{AO}$ & $\mathrm{AB}$ & $\mathrm{B}$ \\
\hline & \multicolumn{3}{|c|}{$\mathrm{Kg} / \mathrm{ha}$} \\
\hline Amonium $\left(\mathrm{NH}_{4}^{+}\right)$ & 15.75 & 1.91 & 1.08 \\
\hline Kalsium $\left(\mathrm{Ca}^{2+}\right)$ & 6.64 & 1.19 & 0.46 \\
\hline Magnesium $\left(\mathrm{Mg}^{2+}\right)$ & 4.48 & 0.47 & 0.08 \\
\hline Kalium $\left(\mathrm{K}^{+}\right)$ & 28.18 & 3.26 & 0.44 \\
\hline Nitrat $\left(\mathrm{NO}_{3}^{-}\right)$ & 192.55 & 37.58 & 33.65 \\
\hline Fosfat $\left(\mathrm{PO}_{4}{ }^{3-}\right)$ & 0.87 & 0.15 & 0.10 \\
\hline Sulfat $\left(\mathrm{SO}_{4}^{2-}\right)$ & 106.19 & 24.25 & 11.21 \\
\hline Klorida $\left(\mathrm{Cl}^{-}\right)$ & 65.59 & 15.32 & 9.22 \\
\hline
\end{tabular}


Hasil uji t pada $\alpha=95 \%$ menunjukan bahwa terdapat perbedaan nyata jumlah amonium dan kalsium pada horizon $\mathrm{AO}$ yang lebih tinggi dibandingkan horizon $\mathrm{AB}$ dan $\mathrm{B}$. Kalium dan amonium memiliki jumlah paling tinggi dibanding kation lainnya. Input bahan organik yang tinggi pada tanah hutan menyumbang jumlah kalium dan amonium lebih banyak dikarenakan kalium lebih mudah dilepas dari hasil dekomposisi bahan organik dibandingkan kalsium dan magnesium (Fahey et al.,1991; Palviainen et al.,2004). Kompleks jerapan tanah cenderung lebih kuat mengikat ion-ion bivalen $\left(\mathrm{Ca}^{2+}, \mathrm{Mg}^{2+}\right)$, sehingga ion monovalen $\left(\mathrm{NH}_{4}^{+}, \mathrm{K}^{+}\right)$lebih lemah terikat dan mudah terdesak oleh kation bivalen dan berada bebas pada larutan tanah (Tan, 2011). Ketika terjadi perkolasi pada kolom tanah, ion-ion terlarut akan secara langsung terbawa oleh sejumlah massa air, sehingga ion kalium dan amonium lebih mudah bergerak pada kolom tanah.

Dapat dilihat pada Tabel 2 bahwa sebagian besar kation terkonsentrasi pada horizon AO. Namun jumlahnya semakin menurun pada horizon $\mathrm{AB}$ dan hanya sedikit yang tersisa pada horizon $\mathrm{B}$. Hal ini menunjukan bahwa tanah memiliki daya jerap terhadap kation terlarut dimana sebagian besar kation diikat pada kompleks jerapan tanah dan hanya sedikit kation terlarut pada lapisan bawah tanah. Mobilitas kation sangat tinggi pada horizon AO dikarenakan input hara dari proses dekomposisi bahan organik dan presipitasi terjadi dominan pada lapisan atas tanah (Cobo et al., 2002). Pada horizon B sebagian besar kation berikatan dengan mineral liat (clay) tanah dan hanya sedikit yang bergerak bebas dalam larutan tanah, dengan begitu hanya sebagian kecil kation pada horizon B yang berpotensi tercuci.

Sama halnya dengan kation, semua anion (nitrat, fosfat, sulfat, dan klorida) memiliki jumlah paling tinggi pada horizon $\mathrm{AO}$, diikuti horizon $\mathrm{AB}$, dan yang terendah pada horizon $\mathrm{B}$ (Tabel 2). Selama selang waktu 138 hari pengamatan, total pencucian nitrat pada horizon AO sangat tinggi sebesar $192.5 \mathrm{~kg} / \mathrm{ha}$ diikuti oleh horizon $\mathrm{AB}(37.58 \mathrm{~kg} / \mathrm{ha})$ dan $\mathrm{B}(33.65 \mathrm{~kg} / \mathrm{ha})$. Fosfat mengalami pencucian tertinggi pada horizon $\mathrm{AO}(0.87 \mathrm{~kg} / \mathrm{ha})$, diikuti oleh horizon $\mathrm{AB}(0.15 \mathrm{~kg} / \mathrm{ha})$ dan $\mathrm{B}(0.10 \mathrm{~kg} / \mathrm{ha})$. Sulfat mengalami pencucian tertinggi pada horizon AO $(106.18 \mathrm{~kg} / \mathrm{ha})$ yang diikuti oleh horizon AB $(24,25 \mathrm{~kg} / \mathrm{ha})$ dan yang terendah pada horizon B (11.21 $\mathrm{kg} / \mathrm{ha})$. Klorida mengalami pencucian tertinggi pada horizon AO (65.59 kg/ha) diikuti oleh horizon AB (15.32 $\mathrm{kg} / \mathrm{ha}$ ) dan terendah pada horizon B $(9.22 \mathrm{~kg} / \mathrm{ha})$.

Hasil uji t pada $\alpha=95 \%$ menunjukan bahwa terdapat perbedaan secara nyata besar kadar jumlah nitrat, sulfat, dan klorida pada horizon $\mathrm{AO}$ yang lebih tinggi dibandingkan horizon $\mathrm{AB}$ dan $\mathrm{B}$. Anion cenderung memiliki jumlah lebih tinggi pada lapisan atas tanah. Ion nitrat memiliki jumlah yang jauh lebih tinggi dibanding anion lainnya diikuti oleh sulfat dan klorida, sedangkan fosfat memiliki jumlah yang sangat sedikit dan jauh lebih kecil dibandingkan anion yang lain. Mineral $\mathrm{N}$ pada larutan tanah dominan dalam bentuk ion nitrat dikarenakan rendahnya afinitas muatan negatif dari mineral klei dan bahan organik terhadap nitrat dan tingginya laju nitrifikasi pada tanah tropis (Renk dan lehmann, 2004 dalam Ghiberto et al.,2014). Klorida sebagai anion monovalen memiliki sifat dan mobilitas dalam tanah yang sama dengan nitrat, klorida hanya sedikit terlibat dalam reaksi tanah (Derby dan Knighton, 2001 dalam Saso et al.,2012). Seperti anion lainnya, sulfat memiliki muatan negatif yang memiliki afinitas lemah terhadap kompleks jerapan tanah. Kekuatan jerapan sulfat dipengaruhi oleh anion lain dimana anion hidroksil $>$ fosfat $>$ sulfat $>$ nitrat/klorida (Tisdale $e t$ al. 1984; Marsh et al.1987dalamMulder dan Cresser, 1994). Hal ini juga menjelaskan mengapa ion fosfat mengalami pencucian paling sedikit dibanding anion lainnya dikarenakan fosfat dijerap kuat oleh mineral klei dan seskuioksida Al dan Fe (Goldberg dan Sposito 1985 dalam Mulder dan Cresser, 1994).

Mengacu pada Tabel 2, nitrat memiliki jumlah jauh lebih tinggi dibanding amonium pada setiap horizon tanah. Seperti yang telah dijelaskan sebelumnya, ion nitrat lebih dominan pada tanah dikarenakan tingginya laju nitrifikasi pada tanah tropis juga afinitas kompleks jerapan tanah yang lebih rendah terhadap nitrat dibandingkan amonium. Hasil yang sama juga diperoleh Blum et al. (2013) yang menunjukan bahwa sebanyak 92.3\% N tanah berada dalam bentuk nitrat dibandingkan amonium. Sedangkan Tian et al. (2007) menemukan bahwa sebanyak 69\% N tanah berada dalam bentuk nitrat.Lebih lanjut, Johnson dan Cole (1980) dalam Sharma dan Sharma (2013) menjelaskan bahwa mobilitas nitrat terutama dipengaruhi oleh proses biologi, fosfat tidak dipengaruhi langsung oleh reaksi permukaan jerapan tanah, sulfat dipengaruhi baikreaksi biologi dan 
reaksianorganik dalam tanah, sedangkan klorida sangat sedikit dipengaruhi oleh baik reaksi biologi maupun anorganik dalam tanah.

\section{Hubungan kation-anion dalam larutan tanah}

Kation yang bermuatan positif dan anion yang bermuatan negatif memiliki peluang untuk saling berikatan dalam larutan tanah (Tan, 2011).Dalam proses pergerakan dan pencucian hara, anion yang bermuatan negatif memiliki kecenderungan membawa kation yang bermuatan positif. Hubungan kation-anion tersebut dijabarkan dengan uji korelasi statistik. Dengan mengetahui nilai korelasi masing-masing kation terhadap anion, dapat menduga ada tidaknya suatu hubungan keterikatan kation dan anion dalam proses mobilisasi di dalam larutan tanah.

Tabel 3 Hasil uji korelasi Spearman kation - anion.

\begin{tabular}{cllll}
\hline \multirow{2}{*}{ Kation } & \multicolumn{4}{c}{ Anion } \\
\cline { 2 - 5 } & \multicolumn{1}{c}{ Nitrat $\left(\mathrm{NO}_{3}{ }^{-}\right)$} & Fosfat $\left(\mathrm{PO}_{4}{ }^{3-}\right)$ & Sulfat $\left(\mathrm{SO}_{4}{ }^{2-}\right)$ & Klorida $\left(\mathrm{Cl}^{-}\right)$ \\
\hline Amonium $\left(\mathrm{NH}_{4}{ }^{+}\right)$ & $0.850^{*}$ & 0.575 & 0.560 & 0.685 \\
Kalsium $\left(\mathrm{Ca}^{2+}\right)$ & $0.853^{*}$ & 0.783 & $0.918^{*}$ & $0.897^{*}$ \\
Magnesium $\left(\mathrm{Mg}^{2+}\right)$ & 0.706 & 0.726 & $0.839^{*}$ & $0.796^{*}$ \\
Kalium $\left(\mathrm{K}^{+}\right)$ & 0.740 & 0.709 & $0.880^{*}$ & $0.874^{*}$ \\
\hline
\end{tabular}

Keterangan: * memiliki nilai korelasi tinggi

Tabel 3 menunjukan bahwa dari keempat jenis anion, nitrat $\left(\mathrm{NO}_{3}^{-}\right)$memiliki korelasi yang tinggi terhadap amonium $\left(\mathrm{NH}_{4}{ }^{+}\right)$dan kalsium $\left(\mathrm{Ca}^{2+}\right)$. Baik Sulfat $\left(\mathrm{SO}_{4}{ }^{2}-\right)$ dan klorida $\left(\mathrm{Cl}^{-}\right)$sama-sama memiliki korelasi yang tinggi terhadap kalsium $\left(\mathrm{Ca}^{2+}\right)$, magnesium $\left(\mathrm{Mg}^{2+}\right)$, dan kalium $\left(\mathrm{K}^{+}\right)$. Sedangkan tidak ditemukan korelasi yang tinggi antara fosfat $\left(\mathrm{PO}_{4}{ }^{3}\right)$ dengan kation manapun. Dapat diketahui bahwa ketiga anion (nitrat, sulfat, dan klorida) memiliki keterikatan/polayang cenderung sama terhadap jenis kation tertentu. Hasil uji korelasi yang diperoleh tersebut kemudian dianalisis dengan regresi linier berganda untuk melihat apakah tiap jenis kation memiliki kecenderungan terhadap anion-anion tertentu. Dilakukan uji regresi linier berganda untuk melihat seberapa besar pengaruh anion-anion terhadap kation.

\section{Hubungan kation-anion dalam pergerakan dan pencucian hara}

Hubungan pengaruh kecenderungan keempat anion (nitrat, fosfat, sulfat, klorida) sebagai peubah $\mathrm{X}$ terhadap masing-masing kation (amonium, kalsium, magnesium, dan kalium) sebagai peubah Y dengan nilai $\alpha=0,01$ menghasilkan persamaan regresi berganda pada Tabel 4 .

Hasil analisis regresi menunjukan bahwa anion berpengaruh sangat nyata terhadap kation. Keempat persamaan regresi kation baik amonium, kalsium, kalium, dan magnesium masing-masing memiliki nilai sign. $F$ yang kurang dari 0,01. Ini menunjukan bahwa keempat anion baik nitrat, fosfat, sulfat, dan klorida secara bersama-sama mempengaruhi pergerakan setiap kation. Dilakukan analisis regresi lebih lanjut dengan metode stepwise untuk mengetahui faktor pembatas dari setiap anion yangpaling mempengaruhi pergerakan masingmasing kation sehingga diperoleh model terbaik. Hasil stepwise terhadap masing-masing anion disajikan pada Tabel 5.

Hasil regresi stepwise pada Tabel 5 menunjukan bahwa amonium dipengaruhi oleh ketiga anion antara lain nitrat, fosfat, dan klorida. Kalsium juga dipengaruhi oleh tiga anion yaitu nitrat, fosfat, dan sulfat. Sedangkan magnesium dan kalium hanya dipengaruhi oleh dua anion dimana nitrat dan fosfat yang mempengaruhi magnesium, sedangkan fosfat dan klorida yang mempengaruhi kalium secara sangat signifikan (Sign. $\mathrm{F}<0.01$ ). Keempat model persamaan regresi stepwise menghasilkan nilai $\mathrm{R}^{2}$ adj. yang cukup tinggi. Dimana amonium memiliki nilai 0.75, kalsium 0.856, magnesium 0.815, dan kalium 0.845. Nilai $\mathrm{R}^{2}$ adj. terendah didapat pada persamaan regresi amonium. Ini menunjukan bahwa model yang dihasilkan dapat menjelaskan bahwa ketiga anion memiliki pengaruh terhadap amonium sebesar $75 \%$, sedangkan $25 \%$ lainnya 
dipengaruhi oleh faktor lain. Peubah $\mathrm{X}$ pada model persamaan regresi kalsium dan kalium dapat mempengaruhi peubah $\mathrm{Y}$ sebesar 85\%. Sedangkan model persamaan regresi magnesium mampu mempengaruhi peubah Y sebesar $81 \%$. Secara umum, lebih dari $80 \%$ pada masing-masing peubah X (anion) mempengaruhi secara signifikan peubah $\mathrm{Y}$ (kalsium, magnesium, dan kalium), dan kurang dari $20 \%$ ditemukan faktor lain yang kemungkinan berpengaruh.

Amonium memiliki kecenderungan positif terhadap ketiga anion. Dimana setiap kenaikan nilai 0.31 ion nitrat, 3.55 ion fosfat, dan 0.083 ion korida akan diikuti dengan kenaikan satu satuan ion amonium. Kalsium, magnesium, dan kalium juga sama-sama memiliki kecenderungan positif terhadap masing-masing anion yang mempengaruhinya. Kenaikan nilai 0.01 nitrat, 1.922 fosfat, dan 0.027 sulfat akan meningkatkan nilai kalsium satu satuan; kenaikan nilai 0.01 nitrat dan 4.08 fosfat akan meningkatkan nilai magnesium sebesar satu satuan; dan kenaikan nilai 17.126 fosfat dan 0.249 klorida akan meningkatkan nilai kalium satu satuan.

Diantara keempat jenis anion, fosfat paling banyak berpengaruh terhadap kation. Dimana fosfat mempengaruhi keempat jenis kation yaitu amonium, kalsium, magnesium, dan kalium. Diikuti oleh nitrat yang mempengaruhi tiga kation (amonium, kalsium, magnesium). Hal ini sama dengan yang dilaporkan Poss dan Saragoni (1992) yang menemukan bahwa ada suatu hubungan yang positif antara anion nitrat dengan kation kalsium dan magnesiumdalam proses pencucian hara. Ion klorida hanya mempengaruhi dua jenis kation yaitu amonium dan kalium, sedangkan sulfat hanya berpengaruh pada kalsium saja. Hal ini sama seperti yang dijabarkan olehChicota et al. (2014) bahwa sulfat memiliki hubungan yang positif terhadap kalsium dimana sulfat bersama-sama dengan kalsium membentuk suatu paired adsorption complex dalam larutan tanah.

Fakta bahwa nilai koefisien fosfat yang lebih tinggi dibanding ketiga anion lainnya pada setiap persamaan model regresi menunjukan bahwa dibutuhkan jumlah fosfat yang lebih tinggi dibandingkan anion lainnya untuk meningkatkan nilai satu satuan kation yang dipengaruhinya. Hal ini dapat dijelaskan karena sifat dari anion fosfat yang sangat imobil dalam tanah. Diketahui bahwa jenis tanah dalam lokasi penelitian merupakan Typic Hapludult yang tergolong masam (Arifin, 2016). Pada kondisi masam, Fosfat bersifat imobil karena membentuk kompleks yang tidak terlarut dalam tanah oleh ion $\mathrm{Al}$ dan $\mathrm{Fe}$, sehingga hanya sedikit fosfat yang berada pada larutan tanah (Do Nascimento et al., 2018; Shenet al., 2011). Do Nascimento (2018) juga menemukan bahwa fosfat yang berikatan dengan amonium bersifat lebih mobil dibandingkan ion kalsium dan magnesium yang berikatan dengan fosfat. Berbeda halnya dengan fosfat, ion nitrat, klorida, dan sulfat yang jumlahnya melimpah dalam larutan tanah (Tabel 2) jika terjadikenaikan sedikit saja pada ketiga anion tersebut maka akan meningkatkan jumlah kation yang lebih besar. Ini menunjukan bahwa nitrat, klorida, dan sulfat memiliki mobilitas yang tinggi dalam proses pergerakan dan pencucian hara dalam tanah dibandingkan fosfat. Pada tanah tropis,sumber utama nitrat dan sulfat adalah hasil dekomposisi bahan organik (Mikkelsen dan Hartz, 2008; Kovar dan Grant, 2011), dan deposisi air hujan (Mulder dan Cresser, 1994),sedangkan sumber klorida terutama berasal dari air hujan (Kelly et al., 2012) yang jumlahnya sangat melimpah. Ketersediaan sumber yang tinggi berimplikasi pada tingginya jumlah hara-hara tersebut yang masuk ke dalam lapisan tanah.

Tabel 4 Hasil analisis regresi linier berganda kation - anion.

\begin{tabular}{|c|c|c|c|c|}
\hline Kation & Model & $\mathrm{R}^{2}$ & $\mathrm{R}^{2} A d j$ & Sign. F \\
\hline $\begin{array}{l}\text { Amonium } \\
\left(\mathrm{NH}_{4}^{+}\right)\end{array}$ & $\begin{array}{l}\mathrm{NH}_{4}^{+}=-0.72+0.27 \mathrm{NO}_{3}{ }^{-}+3.098 \mathrm{PO}_{4}^{3-}-0.16 \mathrm{SO}_{4}{ }^{2-}+ \\
0.115 \mathrm{Cl}^{-}\end{array}$ & 0.768 & 0.745 & $0.000 * *$ \\
\hline Kalsium $\left(\mathrm{Ca}^{2+}\right)$ & $\begin{array}{l}\mathrm{Ca}^{2+}=-0.26+0.007 \mathrm{NO}_{3}{ }^{-}+2.071 \mathrm{PO}_{4}{ }^{3-}+0.019 \mathrm{SO}_{4}{ }^{2-}+ \\
0.021 \mathrm{Cl}^{-}\end{array}$ & 0.869 & 0.856 & $0.000 * *$ \\
\hline $\begin{array}{l}\text { Magnesium } \\
\left(\mathrm{Mg}^{2+}\right)\end{array}$ & $\begin{array}{l}\mathrm{Mg}^{2+}=-0.197+0.006 \mathrm{NO}_{3}{ }^{-}+4.114 \mathrm{PO}_{4}{ }^{3-}-0.005 \mathrm{SO}_{4}{ }^{2-}+ \\
0.02 \mathrm{Cl}^{-}\end{array}$ & 0.827 & 0.810 & $0.000^{* *}$ \\
\hline Kalium $\left(\mathrm{K}^{+}\right)$ & $\begin{array}{l}\mathrm{K}^{+}=-1.087+0.025 \mathrm{NO}_{3}{ }^{-}+17.813 \mathrm{PO}_{4}{ }^{3-}-0.32 \mathrm{SO}_{4}{ }^{2-}+ \\
0.241 \mathrm{Cl}^{-}\end{array}$ & 0.864 & 0.850 & $0.000 * *$ \\
\hline
\end{tabular}

Keterangan: **sangat nyata sign. $\mathrm{F}<0.01$ 
Tabel 5 Model terbaik hasil stepwise.

\begin{tabular}{llccc}
\hline Kation & \multicolumn{1}{c}{ Model } & $\mathrm{R}^{2}$ & $\mathrm{R}^{2}$ Adj. & Sign. $\mathrm{F}$ \\
\hline $\begin{array}{l}\text { Amonium } \\
\left(\mathrm{NH}_{4}{ }^{+}\right)\end{array}$ & $\mathrm{NH}_{4}{ }^{+}=-0.78+0.31 \mathrm{NO}_{3}{ }^{-}+3.55 \mathrm{PO}_{4}{ }^{3-}+0.0835 \mathrm{Cl}^{-}$ & 0.767 & 0.750 & $0.000^{* *}$ \\
Kalsium $\left(\mathrm{Ca}^{2+}\right)$ & $\mathrm{Ca}^{2+}=-0.24+0.01 \mathrm{NO}_{3}{ }^{-}+1.922 \mathrm{PO}_{4}{ }^{3-}+0.027 \mathrm{SO}_{4}{ }^{2-}$ & 0.866 & 0.856 & $0.000^{* *}$ \\
$\begin{array}{l}\text { Magnesium } \\
\left(\mathrm{Mg}^{2+}\right)\end{array}$ & $\mathrm{Mg}^{2+}=-0.187+0.01 \mathrm{NO}_{3}{ }^{-}+4.08 \mathrm{PO}_{4}{ }^{3-}$ & 0.824 & 0.815 & $0.000^{* *}$ \\
Kalium $\left(\mathrm{K}^{+}\right)$ & $\mathrm{K}^{+}=-0.973+17.126 \mathrm{PO}_{4}{ }^{3-}+0.249 \mathrm{Cl}^{-}$ & 0.852 & 0.845 & $0.000^{* *}$ \\
\hline
\end{tabular}

Keterangan: $* *$ sangat nyata sign. $\mathrm{F}<0.01$

\section{SIMPULAN}

Total jumlah massa kation dan anion terlarut pada horizon AO lebih tinggi dibanding horizon $\mathrm{AB}$ dan $\mathrm{B}$. Ion nitrat, sulfat dan korida memiliki sifat pergerakan (mobilitas) yang tinggi dalam larutan tanah dan berpotensi mengalami pencucian paling besar dibanding ion lainnya, sedangkan ion fosfat, kalsium, dan magnesium bersifat lebih imobil dan memiliki potensi tercuci paling rendah. Hasil pemodelan regresi menunjukan adanya pengaruh nitrat, fosfat, sulfat, dan klorida yang secara bersama-sama mempengaruhi pergerakan kation. Setiap anion memiliki pengaruh yang berbeda-beda terhadap kation tertentu. Anion memiliki pengaruh yang positif dalam proses mobilisasi kation dalam larutan tanah dimana ion amonium paling dipengaruhi oleh ion nitrat, fosfat, dan klorida. Ion kalsium paling dipengaruhi oleh ion nitrat fosfat, dan sulfat. Ion magnesium paling dipengaruhi oleh ion nitrat dan fosfat. Adapun ion kalium paling dipengaruhi oleh ion fosfat dan klorida.

\section{DAFTAR PUSTAKA}

Arifin S. 2016. Dinamika Karbon Organik Terlarut pada Toposekuen dan Hubungannya dengan Sifat Tanah di Taman Nasional Bukit Duabelas. Tesis. Bogor: Sekolah Pascasarjana, Institut Pertanian Bogor.

Blum J, Melfi AJ, Montes CR, Gomes TM. 2013. Nitrogen and phosphorous leaching in a tropical Brazilian soil cropped with sugarcane and irrigated with treated sewage effluent. Agricultural Water Management. 117:115-122.

Cichota R, Vogeler I, Bolan NS, Clothier B, Scotter DR. 2014. Sulphate leaching through two contrasting New Zealand soils. The Regional Institute Online Publishing. [terhubung berkala].http://www.regional.org.au/au/asssi/supersoil2004/s13/poster/1496_cichotar.htm

Clare SA, Mack MC. 2011. Influence of precipitation on soil and foliar nutrients across nine Costa Rican Forests. Biotropica. 43(4): 433-441.

Cobo JG, Barrios E, Kass DCL, Thomas RJ. 2002. Decomposition and nutrient release by green manures in a tropical hillside agroecosystem. Plant Soil. 240: 331-342.

Do Nascimento CAC, Pagliari PH, De A. Faria L, Vitti GC. 2018. Phosporus mobility and behaviour in soils treated with calsium, ammonium, and magnesium phosphate. Soil Science Society of American Journal. 82: 622-631.

Erizilina E, Pamoengkas P, Darwo. 2018. Hubungan sifat fisik dan kimia tanah dengan pertumbuhan meranti merah di KHDTK Haurbentes. Jurnal Pengelolaan Sumberdaya Alam dan Lingkungan. 8(2): 216-222.

Eviati, Sulaeman. 2009. Analisis Kimia Tanah, Tanaman, Air, dan Pupuk. Prasetyo BH, Dj. Santoso, L. Retno, editor. Bogor: Balai Penelitian Tanah, Bogor.

Fahey TJ, Stevens PA, Hornung M, Rowland P. 1991. Decomposition and nutrient release from logging residue following conventional harvest of Sitka spruce in north Wales. Forestry. 64(3): 289-301.

Fujii K, Funakawa S, Hayakawa C, Kosaki T. 2008. Contribution of different proton sources to pedogenetic soil acidification in forested ecosystems in Japan. Geoderma. 144(3-4): 478-490. 
Fujii K, Hartono A, Funakawa S, Uemura M, Kosaki T. 2011. Fluxes of dissolved organic carbon in three tropical secondary forests developed on serpentine and mudstone. Geoderma. 163(1-2): 119-126.

Garg AK, Gupta AK, Rani A. 2015. Leaching kinetics of sulphates in acidic soil. International Journal of Plant dan Soil Science. 9(4): 1-11.

Ghiberto PJ, Libardi PL, Trivelin PCO. 2014 .Nutrient leaching in an Ultisol cultivated with sugarcane. Agricultural Water Management. 148: 141-149.

Hartemink AE. 2008. Sugarcane for bioethanol: soil and environmental issues. Advance Agriculture. 99: 125182.

Kelly WR, Panno SV, Hacley K. 2012. The Source, Distribution, and Trends of Chlorides in The Water of Illinois. Ilinois State Water Survey. Illinois [US]: Praire Research Institute, University of Illinois.

Kovar JL, Grant CA. 2011. Nutrient Cycling in Soil: Sulfur. Lincoln [US]: University of Nebraska.

Mikkelsen R, Hartz TK. 2008. Nitrogen sources for organic crop production. Better Crops. 92: 16-19.

Mulder J, Cresser MS. 1994. Biogeochemisthry of Small Catchment: a Tool for Environmental Research. B. Moldan, J. V. Cerny, editor. New York [US]: John Willey dan Sons Inc.

Palviainen M, Finér L, Kurka AM, Mannerkoski H, Piirainen S, Starr M. 2004. Release of potassium, calcium, iron and aluminium from Norway spruce, Scots pine and silver birch logging residues. Plant and Soil. 259 (1-2):123-136.

Poss R, Saragoni H. 1992. Leaching of nitrate, calcium and magnesium under maize cultivation on an oxisol in Togo. Nutrient Cycling in Agroecosystems. 33(2):123-133.

Rahman MW, Purwanto MYJ, Suprihatin. 2014. Status kualitas air dan upaya konservasi sumberdaya lahan di DAS Citarum hulu, Kabupaten Bandung. Jurnal Pengelolaan Sumberdaya Alam dan Lingkungan. 4 (1): 24-34.

Saso JK, Parkin GW, Drury CF, Lauzon JD, Reynolds WD. 2012. Chloride leaching in two Ontario soils: Measurement and prediction using HYDRUS-1D. Canadian Journal of Soil Science. 92(2): 285-296.

Sharma V, Sharma KN. 2013. Influence of accompanying anions on potassium retention and leaching in potato growing alluvial soils. Pedosphere. 23(4): 464-471.

Shen J, Yuan L, Zhang J, Li H, Bai Z, Chen X, Zhang W, Zhang F. 2011. Phosporus dynamics: from soil to plant. Plant Physiology. 156: 997-1005.

Tan KH. 2011. Principle of Soil Chemisthry. Georgia [US]: CRC Press.

Thorburn PJ, Wilkinson SN, Silburn DM. 2013. Water quality in agricultural lands draining to the Great Barrier Reef: a review of causes, management and priorities. Agriculture Ecosystem Environment. 180: 4-20.

Tian YH, Yin B, Yang LZ, Yin SX, Zhu ZL. 2007. Nitrogen runoff and leaching losses during rice-wheat rotations in taihu lake region, China. Pedospher. 17(4): 445-456.

Van der Heijden G, Legouta A, Polliera B, Bréchetb C, Rangera J, Dambrine E. 2012. Tracing and modeling preferential flow in a forest soil: potential impact on nutrient leaching. Geoderma. 195-196: 12-32. 